\title{
Famous Last Words The Maqātil of the Zubayrids in Medieval Islamic Histories
}

\author{
SANDRA S. CAMPBELl (San Diego State University)
}

\begin{abstract}
Death scenes, or maqātil, were used by early Muslim historians to convey the meaning of lives, and to show the righteousness or sinfulness of the historical figures they were reporting about. Careful historians, such as al-ṬABARI or al-BALĀDHURİ, eschewed the most obviously legendary tales, but seem to have exercised leniency when recounting death scenes. Using accounts of the deaths of 'Abd Allāh b. al-Zubayr and his brother Muśab b. al-Zubayr, I argue that the death scenes of these men reflect anxiety later Muslims felt about fighting undertaken by the sahāba and tābi $\bar{u} n$, forebears whom later Sunnis took as exemplars even though they had participated in civil wars against other Sunni figures. Both of these men died fighting for a cause that they likely deemed righteous, which raised the question of martyrdom. Could they be considered martyrs when they had died fighting other Muslims? Their death scenes indicate that these men at least died nobly, heroically fighting for their cause. Whatever their status in the next life, in their death scenes, they are given voices, posthumous though they might be, with which to preserve their memories in an edifying and morally uplifting fashion, and to hint at their ultimate fates.
\end{abstract}

\section{Introduction}

The famous $12^{\text {th }}-13^{\text {th }}$ century historian, IBN AL-ATHĪR, defended the usefulness of historical writing by arguing that the lessons of history encourage intelligent people to forbear in the face of adversity, to take consolation in knowing of the trials suffered by others, and to realize that life and fate in this lower world are arbitrary:

As to the usefulness of history for the other world... truly intelligent persons who reflect about the lessons of history will notice that the world turns its people upside down and plays havoc with its most prominent inhabitants. It takes away their lives and treasures... and neither the rich nor the poor are safe from its misfortunes.... Furthermore, the study of history leads to the acquisition of two very good qualities, forbearance and the habit of taking consolation in the examples of others (alta'ass $\vec{\imath})$.

Although he wrote in the late $12^{\text {th }}$ and early $13^{\text {th }}$ centuries C.E., IBN AL-ATHĪR's comments reflect perceptions of history that long predate him. In the early histories of such ninth- and

1 The translation here is that of Franz Rosenthal except for the definition of al-ta'assī. RoSENTHAL 1968: 299-300; IBN AL-ATHīR, Kāmil, i: 8. 
tenth-century Muslim historians as al-ṬABARĪ and al-BALĀDHURĪ, internal evidence suggests that histories were already seen in their time, if not well before, as repositories of lessons ('ibar) - lessons about temptation and power, heroism and nobility, righteousness and piety. In the case of troubling junctures in the early Islamic past, such as civil wars, historical accounts also functioned to clarify the meaning of that bewildering past.

Some kinds of reports, however, were more useful than others in serving these purposes. Dramatic death scenes, maqātil (sing. maqtal), in particular allowed historians and transmitters to portray character, to edify and inspire noble values, and to treat difficult questions that the memory of the past brought up. ${ }^{2}$ Maqātil, it is argued here, seem to have been considered a type of historical account in which creative transmission (or embellishment) was seen as deserving a relatively free hand. In general, serious historians such as alȚABARĪ, al-BALĀDHURĪ or IBN AL-ATHĪR avoided accounts that were too obviously marked by elaboration, such as patently symbolic reports about men who had, as children, preferred to drink blood over milk. Maqātil however, were likely held to a slightly different standard: their function in histories was to sum up lives, to illuminate the values and the causes for which men and women died, and to provide inspiration through accounts of exemplary suffering. In some cases, they also did more than this; death scenes - the Arabic term maqātil means "scenes (or moments) of killing"-also shed light on two key issues in the historical memory of the early Islamic period: martyrdom and the problem of the righteousness of forebears who took part in civil wars.

\section{The Larger Context: Death Scenes in Literature and Historiography}

The creative embellishment of accounts about how famous forebears faced death is not unique to the Islamic tradition; literary representations of dramatic deaths, especially when those deaths were defined as martyrdom, have a long and distinguished history in Christianity, Judaism, and other traditions. Muslim transmitters' accounts of noble deaths were doubtless affected by the literary traditions of the late antique world in which they were transmitted, just as Muslim concepts of martyrdom were. ${ }^{3}$ Christian martyrologies functioned not only to memorialize those who had died for the sake of the faith but also to inspire potential believers, and to create a sense in readers of a "community of suffering," a sense of identity bolstered by accounts of suffering and self-sacrifice for God, for the

2 On maqātil as a genre of historical writing, see GüNTHER 1994: 192-212 and GüNTHER 1991. Julie Scott MEISAMI dedicated an article to the account given by the eleventh-century Persian historian, Bayhaqī, of the execution of Hasanak in 422/1031. MEISAMI asks rhetorically, "Is this the way things really happened? ... Bayhaqī's purpose is not merely to deliver "the facts" ...but to present [Hasanak] as an emblematic victim of injustice, and thus a universal type.” MEISAMI 1995: 360; Tayeb El-Hibri noted the use of death scenes to portray "a central human and political tragedy where the actor's fall becomes his only salvation from the moral and political disorder generated in the pursuit of power." EL-HIBRI 1999: 94

3 SZYSKA 2004: 36. Angelika Neuwirth argues that "the Islamization of the martyrdom concept took place only during Umayyad rule ... Islam in that era integrated elements of Christian religious culture and theology on a massive scale." NEUWIRTH 2004: 262. Thomas Sizgorich has argued that Muslims incorporated "a late antique koiné of signs, symbols, and narratives they encountered" in the lands they settled after the Islamic conquests. SIZGORICH 2009: 147-164, 276, et passim. 
Truth. ${ }^{4}$ Authors of Christian martyrologies used "stylized, literary representation of the interrogation, torture and death" of martyrs to convey the message that these accounts were accounts about how the battle between good and evil, righteousness and temptation played out in the final moments of human lives. ${ }^{5}$ In some cases, maqātil in Islamic histories are also accounts about the battle between good and evil, or rather, about the human battle to attempt to remain righteous while facing not only certain failure in this lower world but also the inscrutability of God's will. ${ }^{6}$ But death scenes in the Sunni historical tradition differ sharply from Christian martyrologies in that the men (and on occasion women) portrayed by early Sunni Muslim historians were not always clearly defined as martyrs. The early Sunni historical tradition developed in a milieu that was colored not only by late antique Christian martyrological traditions, but also by the accounts of the rival Khārijī and early Shî̀ historical traditions; like the Christian martyrological tradition, the Khārijīs and early Shīis could unabashedly frame the deaths of those who had fallen in battle against “impious" Muslim opponents as martyrs' deaths.

For Sunni historians (and their Sunni audiences), however, a tension existed between several core religious commitments: respect for Prophetic hadith that forbade participation in intra-communal strife, reverence accorded to the Prophet's Companions and their Successors, and the unexpurgated memory that some of the most famous of those Companions and Successors had fought one another unto death. Khārijī and Shīī historical memory was not dogged by this contradiction between theology and history, so the deaths of their respective forebears could be freely represented as martyrdom.

For Sunnis, the early Muslims who had died while fighting (or resisting) pagans or nonMuslims for the sake of Islam (fi sabill Allāh), could easily be deemed martyrs for the faith. Illustrious early Muslims who fought for the sake of righteousness (al-haqq) against other Muslims, however, were more problematic. The question of whether they were sinners or martyrs, whether they had transgressed or had been righteous, remained open to debate. ${ }^{7}$ If esteemed forebears had been killed while fighting against other Muslims, even if they had done so for an apparently just cause, they could not easily be deemed martyrs, since to kill another Muslim was forbidden by the Qur'ān and the Sunni hadīth literature: it was a sin, the punishment for which was consignment to hell. ${ }^{8}$

Some verses of the Qur'ān seem rather unequivocal on the matter, such as the verses found in Sūrat al-Nisā': "It is unlawful for a believer to kill another believer except by accident... He who kills a Believer by design shall burn in Hell forever. He shall incur the wrath of God, who will lay His curse upon him and prepare for him a woeful punishment." (4: 94, 97-8.) Other Qur'ānic verses are less clear: Sūrat al-Hujarāt (9: 9-10) instructs Muslims to solve intra-communal conflicts, but if one group of Muslims transgresses the rights of others, they should be fought: "If two parties from among the Believers fight each other, then make peace between them. But if one of them transgresses against the other, then fight

PANNEWICK 2004a: 9.

BROCK / HARVEY 1987: 14

6 As evinced in the inclusion of maqātil in Islamic literature that treats the issue of forbearing in the face of hardship and tribulations, such as ABŪ 'L- 'ARAB al-Tamīmī's Kitāb al-mihan, "Book of Trials."

7 On this question, see: ABOU EL-FADL 2001, KOHLBERG 1997 and KOHLBERG 1997a.

8 For representative ahadìth on this problem, a good selection, conservative but full, is that of Muslim: Muslim b. al-ḤAJJĀJ, Ṣah̄ịh Muslim, ix: 262 (kitāb al-fitan wa-ashrāṭ al-sāåah). 
against the party that is transgressing (al-fi'a al-bāghiya) until they comply with God's command..."9 The problem faced by historians, jurists, exegetes, and theologians was that the Qur'ân did not expressly address the question of Muslims fighting against the oppression and injustice of other Muslims who happened to command far superior forces. ${ }^{10}$

The Sunni hadith literature on the issue of intra-communal strife was less open to interpretation than were the Qur'ānic verses: many hadīth reports specifically forbade intracommunal strife, treating it under the rubric of fitan. The Prophet is reported to have said, "If two Muslims attack each other with swords, they are both bound for Hell." It was said [to him], "That is for the killer, but what about the one killed?" He replied, "He had intended to kill his opponent." "I In general, the hadith literature, which often reflects postQur'ānic developments of the first and second Islamic centuries, counsels Muslims to avoid conflict, even when their Muslim leaders commit injustices. For historians, the trouble with the quietism promoted by most aḥa dìth, and by nearly all later Sunni credal statements, was that it ran directly counter to the distinctly activist example of many important Companions and their Successors. ${ }^{12}$

Indeed, the question of which individuals among those killed in intra-communal strife during the first century were martyrs rather than sinners became a thorny issue relatively early in the young Islamic community's history: the famous case of Prophet's grandson, alHusayn, having been killed in an attempt to rebel against other Muslims, was especially problematic: was he a rebel or a martyr? The fact that the place of his death was memorialized not long after his death by the Tawwābūn - who visited his gravesite before going to face the likelihood of meeting their own deaths in battle to avenge his killingindicates that al-Husayn was already being understood as a martyr-figure by some Muslims of his generation. Was it proper that this grandson of the Prophet, famed for his piety, should be deemed a sinner by Sunnis? ${ }^{13}$

9 The identity of this group, "al-fi'a al-bāghiya," since clear Qur'ānic leave is given to fight it, has naturally occasioned substantial debate. Any imperfect Muslim group with power could be identified as "transgressing" the rights of another.

10 As noted by ABOU EL-FADL 2001: 38 .

11 The Prophet is similarly reported to have said, "Whoever dislikes something that his leader has done, let him be forbearing, for whoever departs even a hand's span from authority will die as a pagan." (Man kariha min amīrihi shay ${ }^{\text {san }}$, fa-l-yașbur, fa-innahū man kharaja min-a 'l-sulțān ${ }^{i}$ shibr $^{a n}$ māta mìtat ${ }^{a n}$ jāhiliyyah). Variations on ahädīth like these can be found in all major Sunni hadīth collections, in the books on "fitan," and under such categories as "diyāt," and "qu'ūd." These versions are from alBukhārī’s Șahīh (kitāb al-fitan, bāb "idhā 'ltaqā 'l-muslimāni bi-sayfayhimā"). Jurists made reference not only to these ahädith, but also to biographies of the Prophet, and were forced by theological disputes about the problem of Companions and Successors having killed each other to elaborate the divine law in subtle ways. For a brief overview, see $E I^{2}$ s.v. "Katl” (Joseph SCHACHT).

12 ABOU EL-FADL observed that "some jurists went so far as to say that the sole reason God made the Companions fight each other was to teach Muslims the law of rebellion." ABOU EL-FADL 2001: 44. This interpretation of the problematic early Islamic past gives purpose to the conflicts and explains how they expressed God's will.

13 The maqtal of al-Husayn and those killed with him, central to Shîi piety, has received a good deal of scholarly attention particularly in its form as taziya play, from the classic study, Mahmoud Ayoub, Redemptive Suffering in Islam (AyOUB 1978) through AgHAIE 2004 and PINAUlt 2001. For a perceptive treatment of this literature and the topic, see PANNEWICK 2004b. 
Reported dreams could resolve the problem of righteous forbears who were killed while fighting against other Muslims. As Leah KINBERG has pointed out, in medieval Islamic societies, the idea that "anyone who has died may appear in a dream and supply sound guidance" was widespread. ${ }^{14}$ Dreams were understood to be windows onto a reality not accessible to mundane sensory perception; answers given by the dead in dreams were understood to reflect the truth.

One dream account that seems to have been aimed at solving the problem of upright Muslims who were killed while participating in intra-communal strife created an obscure category between martyr and sinner. IBN SA 'D transmitted an account in which Kuthayyir b. Aflah was seen in a dream. Kuthayyir was a Medinan who had been killed during the Battle of al-Harra, at which the Umayyads had defeated the Medinans then plundered their homes and raped their women, before extracting humiliating oaths of loyalty from the surviving men. The dreamer asked Kuthayyir whether or not he was a martyr-and presumably, in the minds of his audience, the deceased Kuthayyir would have already known the answer to the question:

While I was asleep, I saw Kuthayyir b. Aflah in a dream- he had died at the Battle of al-Harra. I realized that he was dead and that I was dreaming.... I called him by his name, and he answered me. I said, "Weren't you killed?" He said, "Yes." I said, "What did you do?" (Mādhā șana'tum?) He said, "Good" (khayr). I asked, "Are you martyrs?" He said, "No, if Muslims meet in battle and a group of them are killed, they are not martyrs. But we are nudaba $\bar{a}^{, 15}$

It is unclear exactly what was meant by $n u d a b \bar{a}$; the root gives meanings of "being forgiven," "praising and bewailing the dead," as well as "appointing substitutes, deputies or delegates." The context makes it clear, however, that it was intended to indicate something reputable, below martyrs but well above sinners in status. ${ }^{16}$

Reported dreams supplied one form of evidence that could be used to solve the problem of early Muslims who fought other Muslims for the sake of righteousness. Reported speech and actions in death scenes provided another form, as is clear in the cases of the maqaitil of two brothers, Muș ab and 'Abd Allāh b. al-Zubayr. ${ }^{17}$ The same kinds of observations made

14 KinBerg 1993: 288. See also KinBerg 1986. Michael Cooperson notes that "evidentiary dreams" were an important form of proof, according to "notions of determinative evidence current among transmitters of polemical narrative." COOPERSON 2000: 129.

15 Ibn Sa'd, Tabaqāt, v: 228 (tarjamat Kuthayyir b. Aflah).

16 LANE 1863: s.v. nūn dāl bä̀. In IBN MANZ̄ūR's Lisān al-'Arab, a hadīth is cited: intadaba allāhu li-man yakhruju fi sabīlihi ayy ajābahu ilā ghufrānihi." Here intadaba means "to grant forgiveness." S.v. nūn dāl bä.

17 For the maqtal scenes of both Zubayrids, I rely here primarily on the full versions given by al-T ABARI and al-BALĀDHURĪ, with occasional reference to other historians' accounts. For the maqtal of Muṣ 'ab: al-ȚABARĪ, Ta'rīkh (ed. Ibrahim), vi: 151-62 (= ed. De Goeje, Annales, ser. ii, 804-813); corresponding English translation, al-ȚABARĪ, Victory of the Marwānids, 177-188 (my translations of cited passages make use of Fishbein's translation, but also differ from it); al-BALĀDHURİ, Ansāb (ed. Goitein), v, 331355. Parallel accounts are found in: IBN AL-ATHĪR, Kämil, iv: 323-336; al-DīNAWARĪ, al-Akhbār alTiwal, 311-315; Ibn A' tham al-KŪFĪ, al-Futūh, vi: 260-270; al-YA 'QŪBĪ, Ta'rīkh, ii: 264-66; Khalīfa b. KHAYYĀṬ, Ta'rīkh, 205-206; al-MAs 'ŪDĪ, Murūj, iii: 112-117; IBN KATHĪr, Bidāya, viii: 29-302 (sub 
here about the Zubayrids could be made about the maqātil of yet more famous fallen Companions and Successors, such as 'Uthmān, al-Zubayr, and others, although in the cases of the individuals such as 'Alī and al-Husayn, who were given the status of martyred imams by the Shīiss, different considerations also apply. Others, such as Muslim b. 'Aqīl, were also the beneficiaries of dramatic, heroic death scenes that functioned to prove the righteousness of their failed endeavors. ${ }^{18}$

Maqātil also furnished historians with rhetorical tools for establishing the reprehensible nature of some historical figures. The maqtal of al-Mukhtār given by al-ṬABARI, for example, includes remarks made by him that "show" that he was motivated by ambition, not by religious commitment. Although al-Mukhtār was generally reviled in Sunni historiography, in the specific case of Ibn A'tham al-KŪFİ's history, al-Futūh, the maqtal of al-Mukhtār is redemptive, dramatic and laudatory: al-Mukhtār's last words tell us that he was content to die after having achieved his noble aim of avenging the blood of the members of ahl albayt killed at Karbalä. ${ }^{19}$

\section{The Maqtal of Muṣ ab b. al-Zubayr}

Some years after 'Abd Allāh b. al-Zubayr won recognition as caliph, he appointed his handsome, brave and generous younger brother Mușab to the governorship of Iraq (c. 687 C.E.). ${ }^{20}$ Shortly thereafter, the young Muș ab led an army against his most important competitor for power in Iraq, al-Mukhtār, whom he vanquished and killed, thereby consolidating Zubayrid power in Iraq. ${ }^{21}$ Zubayrid rule was challenged by many rebellions in the next few years but must have initially seemed at least as likely to succeed as did Umayyad rule. However, in 72/691 the Umayyad caliph, 'Abd al-Malik, personally led an army against Mușab and his Zubayrid forces in an attempt to dismantle the Zubayrid state and consolidate Umayyad power. ${ }^{22}$

anno 71); al-IȘFAHĀNī, Aghānī, xix: 84-92 “maqtal Muṣ'ab b. al-Zubayr." The year under which most historians treated Mus'ab's maqtal is 72 A.H.

18 Among the most moving accounts of the maqtal of Muslim b. 'Aqīl, the cousin of al-Husayn sent to Kufa to prepare or al-Husayn's arrival, is that given by Ibn A'tham al-Kūfĩ: al-KūFī, Futūh, v: 92-103.

19 al-KūFī, Futūh, vi: 190-191, 196-8

20 The appointment is reported in al-ȚABARİ, Annales, ser. ii, 716-717; al-YA'QūBĪ, Ta'rīkh, ii: 264; alBALĀDHUR̄̄, Ansāa, v: 234, 273; IBN AL-ATHĪR, Kāmil, iv: 266-267. Muṣáab’s generosity, handsome face, and humility are nearly universally remarked upon in the histories. See al-Balādhurî’s short tarjama of Muș'ab: al-BALĀDHURĪ, Ansāa b, v: 59.

21 Al-ȚABARĪ, Annales, ser. ii, 718-750, sub anno 67; al-BALĀDHURī, Ansāb, v: 260-273 (under "maqtal al-Mukhtār"); IBN AL-ATHĪR, Kāmil, iv: 267-72. Ibn Kathīr, in his tarjama of Muṣ́ab, discussed the problem of Mușab's having killed all of al-Muhktār's supporters after having given them a promise of safe passage. He cited the Quranic verse, Sürat al-Nisāa, v. 93, in which the punishment for killing a fellow Muslim is spelled out as eternal damnation. IBN KATHĪR, Bidāya, viii: 303.

22 Al-YA 'QŪBĪ gave the year 71 A.H.: Ta'rīkh, ii: 265. Al-MAs' ŪDĪ placed the death of Muș ab in year 72.

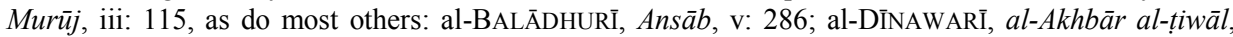
319; Khalīfa B. KHAYYĀṬ, Tảrīkh, 205; IBN KATHĪR, Bidāya, viii: 299; al-KHAȚīB, Ta’rīkh Baghdād, xiii: 108. Al-TABARI, dating this battle to the year 71, acknowledged the disagreement about the date (Annales, ser. ii, 813). The problem with the date might be due to the fact that the first time that 'Abd 
Al-ṬABARĪ tells us that when the two forces met at Dayr al-Jāthalīq, 'Abd al-Malik had already cleverly sent letters to the tribal leaders of Muș ab's army before they joined battle. Mușab's sole trustworthy general present at the battle, Ibrāhīm b. al-Ashtar, is said to have brought his letter, unopened, to Muș ab. ${ }^{23}$ Muș ab read it: it contained 'Abd al-Malik's offer to Ibrāhīm of the governorship of Iraq if he would desert Muș ab. Ibrāhīm warned Muṣ ab that all of the rest of his generals had received similar letters from 'Abd al-Malik.

Thus the battle, in al-ṬABARI's narrative, is dramatically set up for his readers, who know that Mușab's generals have been bribed by 'Abd al-Malik. ${ }^{24}$ Only Ibrāhīm b. alAshtar has remained loyal to Mușáab. Nonetheless, alerted that he was doomed, Mușab continued with his battle plan, and the armies engaged. Ibrāhīm advanced, forcing back 'Abd al-Malik's army, but then Umayyad reinforcements were sent, and the loyal Ibrāhīm was killed. Mușab called for his reinforcements - one by one, he called his generals to advance. Each in his turn refused.

Al-ṬABARĪ, transmitting from al-Madā'inī and al-Haytham b. 'Adiyy, relates that at this point, 'Abd al-Malik sent an offer of safe passage to Muș ab. Muș ab rejected the offer, but when his son 'İsā received a similar offer, he encouraged him to take it. 'İsa refused, saying: "Let not the women of Quraysh say that I delivered you up to be slain." ${ }^{25}$ Mușab responded, "Then advance in front of me, and I will reckon on being rewarded by God for suffering your death during my lifetime." So Muș'ab's son 'Īsā went out to the battlefield in front of Muśab and fought until he was killed. ${ }^{26}$ In al-MAS 'ŪDĪ's narrative, this dramatic moment is heightened: just as Mușáab was being urged to accept an offer of safe passage called out to him by one Umayyad soldier, another Umayyad soldier came forward to behead the body of his fallen son, 'İsā. Muș ab, unable to resist the impulse to defend his son's body, rushed out to attack that Umayyad soldier, but then his horse was hit and crippled; as he stands on the ground fighting, he is filled with wounds, killed with a final stroke of the sword, then himself beheaded.

In al-ṬABARĪ's narrative, after his son's death, Mușab is wounded by an arrow, struck by a spear, thrown to the ground and beheaded. His head was then brought to 'Abd alMalik. 'Abd al-Malik paused and asked rhetorically, "When shall the women of Quraysh bear the like of Mușab?"27 Then he ordered his men: "Bury him-by God, we used to honor one another, but kingship is a barren and destructive thing.,"28

al-Malik and Mușab took forces out to fight, they did not engage in battle, but returned the following year. See 'ABD DiXON 1971: 134.

23 It bears noting that the father of Ibrāhīm b. al-Ashtar had been 'Alī's most loyal and energetic general in the battle of Siffīn. Ibrāhīm himself was first a general in al-Mukhtār's forces, but went over to the Zubayrids either slightly before or after al-Mukhtār's death. See al-BALĀDHURĪ, Ansāb, v: $336 \mathrm{f}$.

24 There are other ways in which the battle is dramatically set up for the audience-poetry is recited that foreshadows the outcome of the battle, for instance.

25 Al-ṬABARĪ, Annales, ser. ii, 809, according to an account transmitted from al-Haytham b. 'Adī; a similar account was transmitted by 'Umar b. Shabbah, 807-809.

26 Al-MAS' '̄DĪ, Murūj, iii: 115.

27 This line is from the narrative of al-MAS 'ŪDI, Murūj, iii: 115

28 “Wārūhu, fa-qad wallāhi kānat-i 'l-ḥurma baynī wa-baynahu qadīmat ${ }^{a n}$ wa-lākin hādhā 'l-mulk 'aqūm. In Ibn Kathīr's account, 'Abd al-Malik states that Muș'ab was among the people he most loved, but that kingship is a barren thing. IBN KATHĪR, Bidāya, viii: 306. 
Now, to those familiar with the maqtal of al-Husayn, this version of the maqtal of Muşab must have seemed vaguely familiar. The maqtal of al-Husayn is more elaborate and dramatic, in all of aspects. But the basic elements of the story are common to both: the perfidy of the Iraqi tribal leaders, the sending off of sons and loyal supporters to battle before one goes to battle oneself, and the hopelessness of the battle against a much larger, more powerful army, combined with the hero's refusal to accept a guarantee of safety. This parallelism did not escape medieval Muslims: the story of Mușab b. al-Zubayr's maqtal, and the proximity of his grave to Baghdad, led later Iraqi Sunnis to invent a religious ritual - a procession to his grave - that paralleled the Shî1 tradition of commemorating the death of al-Husayn. $^{29}$

'Abd Allāh b. al-Zubayr's khuṭba (sermon) on the death of Muṣab is often recounted in the historical sources. ${ }^{30}$ Indeed, it often functions as a sort of link between the end of the maqtal of Muș ab and the beginning of the final battles and maqtal of 'Abd Allāh himself. Muṣ ab had been 'Abd Allāh's greatest strength in Iraq, and through him he had maintained his control of the provinces east of Iraq. In a single battle, the largest and richest part of 'Abd Allāh's territory had slipped out of his hands; with the defeat and death of Muśab, he had lost not only his most important territories, but also his most powerful governor, general, and supporter.

Later historians knew well that this defeat spelled the beginning of the end for 'Abd Allāh b. al-Zubayr. This was doubtless clear even at the time of the events. It is reported that for some days, Ibn al-Zubayr did not acknowledge the death of Mușab publicly, until "even the slaves of Medina and Mecca talked about it in alleyways.",31

When he finally ascended the minbar to address publicly news of his brother's death, he first waited for several minutes in silence, we are told, his brow covered with sweat, and distress apparent on his face. ${ }^{32}$ Then he began his speech. In the report transmitted by alBALĀDHURĪ, he began by praising God "to Whom belongs creation, authority, and sovereignty of this world and the Hereafter." ${ }^{, 33}$ In other words, he first praised God, whose will, he acknowledged, was being expressed in the unfolding of events. The next line of his reported khutba is even more explicit: "He gives dominion (mulk) to whomever he wills, and he takes it away from whomever He wills; He exalts whom He wills, and abases whom He wills; it is from Him that goodness comes, and He is powerful over all things."

Ibn al-Zubayr's khutba, as it was remembered, thus addressed the problem of the discrepancy between God's will, as demonstrated through victory given in battle-God certainly seemed to be backing the Umayyads - and the Zubayrid belief that it was they who were fighting for the sake of righteousness, and thus they who should have received God's blessing. The sermon first affirms that God is owed praise for all things; He is all-

29 That commemoration I have treated at length elsewhere. See CAMPBELL 2003.

30 This is found in al-BALĀDHURĪ's Ansāb, v: 347-8; al-ṬABARĨ , Annales, ser. ii, 818-819; IBN AL-ATHĪr, Kāmil, 335-336; al-IȘFAHĀNī, Aghānī, xix: 89-90.

31 Al-MAs' ŪDĪ, Murūj, iii: 119; al-BALĀDHURĪ, Ansāb, v: 347; al-IȘFAHĀNī, Al-Aghān̄i, xix: 89. AlȚABARİ did not transmit this detail.

32 Al-BALĀDHUR̄̄, Ansāb, v: 347-348.

33 The account of al-BALĀDHURI is more detailed than the parallel account of al-ȚABARI, and forms the basis for the translation given here. See also al-MAS 'ŪDĪ, Murūj, iii: 119, IBN AL-ATHĪR's Kāmil, iv: 335-336; al-ṬABARİ, Annales, ser. ii, 818-819. 
powerful, and it is He who determines who shall achieve earthly power, abasing or exalting whomever He chose. It then goes on, however, to refine the concepts of debasement and exaltation: "God does not abase the man who has righteousness on his side, nor does $\mathrm{He}$ exalt any man among the supporters of falsehood (al-bätil), even if all people should be on the side of the latter." 34 In other words, even if the righteous should lose the battle on earth, they have not lost the battle for righteousness in the eyes of God; even if they should lose earthly dominion, they have not lost their places in the Hereafter.

Ibn al-Zubayr is said to have then asserted that the news of Muș ab's death in Iraq both gladdened him and saddened him; although saddened by the loss of a beloved friend, "yet the man of judgment, religion, intelligence and understanding then embraces fitting forbearance and noble consolation." He specified that what had gladdened him was the knowledge that Mușab had died a martyr (qatluhu shahäda) and that "God made that an option for him and for us." 35 He next condemned the Iraqis for betraying his brother, and compared the trial of Mușab's death to similar trials already endured by other noble Muslims, such as the assassination of 'Uthmān. He concluded by reminding his listeners, "This world is but a loan from the All-Powerful King, whose dominion endures, whose sovereignty is ever-lasting; if it turns toward me, I shall not take it like a conceited ingrate; if it turns away, I shall not cry over it like a senile old man." In other words, he asserts his own humility, his piety and his concern for the Hereafter in one final sweeping remark. AlBALĀDHURĪ's account has 'Abd Allāh descend from the pulpit reciting a line of poetry that reflects his awareness of his impending doom: "Take me, O Hyena, drag me, and be gladdened/ by the meat of a man whose supporter did not live till today." 36

This speech not only presages 'Abd Allāh's death, it treats some of the crucial issues that faced later Muslims living with the memory of the strife that had torn asunder the early Muslim community: could God forsake those who tried to live righteously and to fight for the sake of Islam? Was victory in battle a barometer of God's favor, or did it only bring the fruits of this world? Was it possible to categorize a death meted out by other Muslims as martyrdom? And, by implication, the question is raised: is this life, filled as it is with trials, with mistakes, with defeats, and with injustices gone unpunished, merely one long test, which the believer must ceaselessly try to pass?

\section{The Maqtal of 'Abd Allāh b. al-Zubayr}

The story of the death of 'Abd Allāh himself at Mecca is yet more dramatically presented by al-ṬABARI than is Mușáab's death. ${ }^{37}$ Al-ṬABARĪ relied heavily upon al-Wāqidì for his

34 In the accounts of al-ṬABARĪ, al-MAS ' ŪDĪ, and IBN AL-ATHĪR the word used instead of "al-bāțil" is "alShayțān."

35 Al-BALĀDHURĪ, Ansāa, v: 348. Michael FISHBEIN chose to translate shahāda as "testimony," although in a footnote he gave "martyrdom" as an alternative; in this context, however, it should be translated "martyrdom." Al-ṬABARĪ, Victory of the Marwānids, 194, note 700.

36 The line is "khudhīñ fa-jurrīñ dibā'a wa-abshirī / bi-lahmi 'mri' in lam yashhadi 'l-yawma nāșiruhu."

37 The reverse is true of al-Dīnawarī, who gives an extremely short account of the maqtal of 'Abd Allāh. Al-DīNAWARĪ, al-Akhbār al-tiwāl, 314-315. The maqtal of Ibn al-Zubayr plays a large role in most tarājim of 'Abd Allāh b. al-Zubayr as well as in histories covering the second fitna. The dialogue with 
narrative of the fall of 'Abd Allāh b. al-Zubayr. After 'Abd al-Malik had defeated Muṣ ab, crushing 'Abd Allāh was his next goal. He sent al-Hajjāj, the harsh and infamous henchman of the early Umayyads, against 'Abd Allāh.

Al-Hajjāj and his forces first besieged 'Abd Allāh and the Zubayrids at Mecca for several months, to starve them into submission. Catapults were set up, and Mecca was bombarded. Having earlier lost most of the provinces that had originally recognized him as caliph, 'Abd Allāh could not now retain even his supporters in Mecca. Al-Hajjāj offered Ibn al-Zubayr's supporters safe passage if they would leave Mecca, and as the months passed, most of 'Abd Allāh's supporters, including two of his sons, accepted the offer and left. 'Abd Allāh's blind and aged mother, Asmā', the daughter of Abu Bakr, remained in Mecca with her son.

Al-ṬABARĪ, al-BALĀDHURĪ, IBN AL-ATHĪR, and many other historians relate that 'Abd Allāh went to talk with his mother when he saw that his supporters were forsaking him. "Mother," he is reported to have said, "my people have forsaken me, even my two sons and my family. Only a few people remain, and they do not have the endurance to defend themselves for more than a short time. The enemy will give me whatever I want from this present world [a governorship in exchange for recognizing Umayyad authority.] ${ }^{38}$ What is your advice?" His mother reportedly answered:

My son, you yourself know best. If you know that you are right and have been pursuing what is right (al-haqq), then persevere in it, since your supporters have been killed while in the right.... But if you only desire the present world, then what a wretched servant of God you are- you have destroyed yourself and those who were killed fighting with you. If you say, 'I was in the right, but when my companions grew feeble, I became weak', that is not how free men and men of religion, act. How long will you last in this world? To be killed is better!

'Abd Allāh drew near and kissed her head, and said:

By God, this is my opinion too. By Him to whom I have been calling men until this very day, I have not inclined to the present world, nor have I loved life in it. Nothing but indignation for God's sake, and that His sacred territory not be profaned, made me rebel. But I wanted to know your opinion, and you have increased my own firm belief. Mother, I will be killed today - let your grief for me not be severe; submit to God's command, [and take comfort that] your son never intentionally did anything dishonorable or indecent: he was not unjust in applying God's laws, he betrayed no trust, nor did he wrong any Muslim or any confederate (mu'ähid.) If I heard of any injustice committed by a governor, I never let it pass: I reproved them for it. I have never preferred anything to my Lord's approval. O God, I do not say this to justify

his mother is nearly always featured. Here I rely primarily upon the maqtal as found in al-ṬABARİ's and al-BALĀDHURĪ's works. Al-ṬABARĪ, Annales, ser. ii, 844-852, al-ṬABARĪ, Victory of the Marwānids, 224-232; al-BALĀDHURĪ, Ansāb, v: 360-373.

38 Al-ṬABARĨ does not explain this in this account, which was transmitted by Muhammad b. Sa'd from alWāqidī. The translation here draws heavily from but does not duplicate Michael Fishbein's able translation: Victory of the Marwānids, 226. 
myself-You know me best! I say this to comfort my mother so that she might endure losing me with forbearance. 39

Needless to say, this exchange has clearly been fabricated or elaborated by biographers and historians. The issue of authenticity can hardly be at stake here-reported conversations are highly unlikely to contain much (if any) authentic material, as NOTH and CONRAD have observed. ${ }^{40}$ Rather, this dramatic exchange is a rhetorical vehicle in which a once-important contender for the leadership of the Islamic community is given a voice with which to vindicate himself to posterity. As a character in the unfolding drama of the umma's experience on earth, Ibn al-Zubayr responds in this exchange to his mother's questions about his motives by establishing his reputation: he never wronged anyone, he tried to be an upright Islamic leader, he only attempted, out of a sense of indignation that the Muslim community was being led astray, to set things aright. He did not, he is portrayed as clarifying, seek leadership for worldly gain, but rather for God's approval-it was not by ambition that he was motivated to act, but by a sense of religious righteousness.

It is not coincidental that Ibn al-Zubayr's speech in this passage shifts from addressing his mother to addressing God: "I have never preferred anything to my Lord's approval. $O$ God, I do not say this to justify myself-You know me best! I say this to comfort my mother so that she might endure losing me with forbearance." The author/s of these words may have thought the speech had begun to seem a little too clearly aimed at establishing the righteousness of Ibn al-Zubayr's cause, or a bit too much like vaunting. Therefore, a justification was included: Ibn al-Zubayr is made to claim - to God-that he is saying all of this to comfort his mother, who is about to suffer the loss of her son. This rhetorical strategy helps to persuade the audience of the authenticity (and decency) of Ibn al-Zubayr's defense of his reputation.

Throughout this exchange, his mother is positioned as a foil: she asks, he answers; she advises, he responds; she will suffer, he will die. Why does she ask? In order to allow the audience to read or hear his answers. She is dramaturgically positioned as the voice of the good Muslim who is given the chance to speak to this historically important character. What does she ask? She asks whether he was fighting for the sake of righteousness or notthe question for which Muslims would have wanted to have the answer. Had not God shown approval for the Umayyad cause by granting them victory? Surely some people suspected that Ibn al-Zubayr was just another self-serving man driven by ambition for worldly power. How could one know?

One could perhaps never know what God thought of all of this, but to get Ibn alZubayr's own final appraisal of his earthly career helped to establish a basis upon which to

39 Al-ȚABARĪ, Tảrīkh (ed. Ibrāhīm), vi: 188-189 ; Annales ser. ii, 846; Victory of the Marwānids, 226. Versions of this exchange abound in biographical entries on 'Abd Allāh, such as those by Ibn Khallikān, al-Ṣafadī, and al-Suyūțī. The dramatic value of this exchange was well-recognized by Muslim authors: it provided a summary of 'Abd Allāh's character and motivations, while affirming the noble character of his mother Asmä' bint Abī Bakr. Stories about Asmä’s noble comportment after the death of her son, too, left a strong mark in the minds of both modern and medieval Muslims. Bayhaqi used her story as an example of how forbearing mothers could be in the context of his description of the execution of the Ghaznavid vizier, Hasanak, and his mother's brave response. MEISAMI 1995: 360-361.

40 NOTH/CONRAD 1994: 87-96 
formulate a judgment of him. This is the backdrop against which this exchange is to be read: the question that the transmitters and historians were answering was, "Who were the righteous ones in this struggle?" The best voices that they could use in answering this question were the historical actors' own voices. ${ }^{41}$

As is well known, according to the logic of this historiographic tradition, historians lost authority if they supplied the audience directly with their own understanding of events: instead, they had to allow historical actors and witnesses to speak directly to the audience of the text, so that readers might infer from their reported words and deeds what had motivated them. ${ }^{42}$ Readers could not be directly told what the import of events might be, or what motivated people, since to assume that one could speak authoritatively about other people's motivations was to call into question the reliability of one's account. This naturally affected how accounts were crafted: they had to be cast as dialogue overheard, speeches made publicly, and actions witnessed.

In case the exchange between Ibn al-Zubayr and his mother itself was not enough to establish his status as a righteous early Muslim - if not a martyr-historians included other clues. When Ibn al-Zubayr went to embrace his blind mother, she felt that he had on a coat of mail and a helmet. She told him to take them off, saying, "This is not the action of someone who intends what you intend." He then took off the helmet and chain mail, the more easily to be killed. This point would not have been lost on the original intended audience of the account, who knew that to go into battle unprotected by a coat of mail was to seek a distinctly more noble death, a more clearly delineated martyrdom. ${ }^{43}$ His mother, knowing that her son was about to meet his death, encouraged him to mark it as a martyr's death. It is only through this device, through her urging him to remove his coat of mail and his reported compliance, that the audience discovers that Ibn al-Zubayr went into the battlefield without armor, the more easily to be killed.

The intended audience was also assumed to know that the practice of sending one's children out to battle to die as martyrs or heroes was a recognized way of gaining reward in the afterlife, as recompense for trials and afflictions suffered in this life. ${ }^{44}$ It was a particularly grueling form of pious suffering to lose one's children in battle before one's very eyes. Al-Husayn, Muṣ ab, and Asmā' bint Abī Bakr, among many others, are remembered to have allowed or encouraged their sons to go to battle before them to be slain.

At their final goodbye, Asmā' is reported to have remarked to her son, "Whoever else may have been killed while in error, you shall have been killed while in the right." She then yielded him to God, declaring her contentment with God's will and decree.

41 On the relationship between the isnād and the way that an account is recounted, see Daniel Beaumont's fascinating article (BEAUMONT 1996).

42 Tarif KHALIDI quotes al-MAS' ŪDĪ's statement (in Murūj) that his readers must "deduce from what we have recorded our intent, which we omitted to record." Al-MAS'ŪDİ candidly admitted that his interpretation of history colored his work, but that he would not comment directly on the meaning of historical events. KHALIDI 1975: 128, note 3.

43 Voluntarily seeking martyrdom was considered praiseworthy. It is related that the Prophet had encouraged Ibn 'Afrā' to "plunge into battle" without armor. See KOHLBERG 1997: 7-11. In IBN KATHĪR's version of this exchange, Asmā', upon feeling the coat of mail, said, "O my son, this is not what one who wants martyrdom (al-shahäda) wears." IBN KATHĪR, Bidāya, viii: 315.

44 On this, see LANE 1863: s.v. " $h \vec{a}$ ' $\sin b \vec{a}$ " (ihtasaba). 
After consulting with his mother, 'Abd Allāh, we are told, went out to fight. He fought valiantly, "like a lion in a thicket," till at last someone threw a brick that struck his head. Blood poured down from his face, and he recited

$$
\begin{gathered}
\text { It is not on our heels, [fleeing,] that our wounds bleed } \\
\text { but rather on our feet, [as we advance]. }
\end{gathered}
$$

The enemy gathered against him, and he repelled them several times. But he could not forestall fate, and finally, he was slain. Al-Hajjāj had him beheaded, and his body impaled. Ibn al-Zubayr's corpse was displayed so that everyone could see "God's judgment," since, for the Umayyads, victory showed that God was on their side. But the story's later audience understood that 'Abd Allāh, no matter what his previous mistakes may have been, had met his death nobly, having fought with the conviction that he was fighting for al-haqq, for God, for the Truth, for pious righteousness.

This has been made clear through the reported dialogue with his mother, as well as by reported words and actions: his intimating in the khutba that martyrdom would be his fate, his decision to fight unto death for his cause, unprotected by armor, and the heroism attributed to him in his last battle. The reported actions, dialogues, speeches and poetry act in concert, in this case as in others, as effective rhetorical tools used by transmitters, historians and biographers to establish the nobility of character, righteousness, piety, and the redemptive suffering of the often flawed subjects of maqātil. ${ }^{46}$

While the content of many maqātil were obviously aimed at addressing questions about character and hinting at ultimate fate, it is less obvious that these accounts were considered directly inspirational. However, internal evidence confirms for us that stories of how noble men had bravely persevered in their causes and met their deaths in battle rather than capitulate were indeed considered inspirational. Al-ȚABARI, in his treatment of the maqtal of Mușab b. al-Zubayr, includes an account related by 'Urwa b. al-Mughīra b. Shu'ba. In this account, 'Urwa reports:

Mușab came marching out [to the battlefield.] He was leaning on the mane of his horse, looking right and left at the men. His eye fell on me. He said, "Urwa, come here.' I went over to him. He said, 'Tell me about al-Husayn b. 'Alī, [about how] he acted in refusing to submit to the judgment of Ibn Ziyād, and his resolve to fight.' Then he [Muśab] recited two lines of poetry that invoked the example of al-Husayn: 'Those of the Bānū Hāshim [buried] at al-Ṭaff [Karbalā'] were consoled by the no-

45 These lines are said to have been recited by him in many versions of this scene: al-T ABARĪ, Annales, ser. ii, 851; al-BALĀDHURĪ, Ansāb, v: 365; IBN KATHĪR, Bidāya, viii: 315; IBN AL-ATHīR, Kāmil, v: 357. The very same lines are sometimes attributed to Ibn al-Zubayr's brother 'Amr, who was sent against him by the Umayyads before the first siege of Mecca, in the year 60. See al-ṬABARI, Annales, ser. ii, 227. If we assume historians to have been extremely clever craftsmen, this would be significant. However, I suspect it merely reflects a vague association between these two verses and the career of Ibn al-Zubayr.

46 For a modern example, see remarks made by the editor of al-TANŪKHĪ's al-Faraj ba'd al-shidda, 'Abbūd al-Thālijīi, who concludes a 26-line long footnote on 'Abd Allāh by saying, "'Abd Allāh b. alZubayr ended his life with a deed of bravery and sacrifice rarely equaled." He then gives, in very brief form, the encounter with Asmā' and the climax. al-TANŪKHĪ, al-Faraj, i: 169-70. 
ble suffering endured by others before them/ they set the example of noble men drawing consolation from the suffering of others. ${ }^{47}$

'Urwa ends his report by saying "And I knew then that he would not turn away until he was killed." 48 In other words, "Urwa is portrayed as having understood, upon hearing Muș'ab's request that the story of al-Husayn's maqtal be retold to him—and upon hearing Mușab recite these two lines of poetry - that Muśab himself wanted to draw inspiration from the story of al-Husayn's maqtal, in order to prepare himself to face his own impending death nobly. The maqtal of al-Husayn is invoked as an inspirational text in this account, and poetical reference is made to al-Husayn and those killed with him, at al-Taff/Karbalä), having taken consolation in recalling the trials endured by yet others before them as well.

In the parallel account given by al-DīNAWARĪ in his al-Akhbār al-țiwāl, 'Urwa tells Muşab the story of how al-Husayn was presented with terms of surrender that he could not accept, and how he refused them to instead face death with forbearance. Then, citing the same lines of poetry, Muș ab decisively whips his horse into action. ${ }^{49}$ In DīNAWARĪ’s report, the ordering of events make it clear that Muṣab should be understood to have heard the story of al-Husayn, to have drawn inspiration from it to act in like manner, and to have immediately acted.

Such accounts show that certainly by the early $3^{\text {rd }} / 9^{\text {th }}$ century (though likely by the late first century) certain maqâtil were understood as inspirational accounts. ${ }^{50}$ This point is underscored both in the lines of poetry reportedly recited by Muśab - the lines that he recites specifically mention taking consolation in the example of others who have suffered before - and in the interpretation of his act of reciting those lines: "and I knew then that he would not turn away until he was killed."

To the question of whether or not the men whose deaths were retold and memorialized in these accounts were martyrs, hints were given: Mușab's maqtal suggests that his case was parallel to that of al-Husayn; 'Abd Allāh's maqtal includes clear indications that he (and his mother) saw his impending death as martyrdom, and that worldly gain was not what he really sought, but rather the Hereafter. For the historians and transmitters of the

47 The poetry recited on this occasion was translated by LANE 1863: i, 87 s.v. "alif-lām-yâa ("ūllī"); also i, 60, “alif-sīn-wāw. The bayt is "wa-inna 'l-ülā bi-'l-Taffi min āli Hāshim / ta'äsaw (or: ta'assaw) fasannū lil-kirāmi 'l-ta'äsiya (or: al-ta'assiya)." It seems highly improbable that the Hāshimīs who died at al-Ṭaff were praised for their generosity instead of for their suffering and forbearance. The verse, attributed to Sulaymān b. Qatta in al-IȘFAHĀNİ’s Kitāb al-aghānī, is there given with the mașdar of the fifth form, which fits the meaning better; in the version of al-ṬABARİ's Ta'rīkh edited by Muhammad Abū al-Faḍl IBRĀHĪM, it is also given as ta'assaw/al-ta'assiya, reflecting that editor's similar preference for the meaning that I have chosen here; the same choice was made for al-Balādhurī's report: alBALĀDHURī, Ansāb, v: 339.

48 Variations on this report are given in al-IȘFAHĀNĪ, $A g h \bar{a} n \bar{l}$, xix: 89; al-BALĀDHURī's Ansāb, v: 339.

49 This detail is from al-DīNAWAR̄̄, al-Akhbār al-țiwāl, 311. In al-Balādhurī's report (from 'Awāna), Mușab recites the line directly after being told that his Iraqi generals had deserted him, which makes the link to al-Husayn's situation strong and clear. Al-BALĀDHURĪ, Ansāb, v: 338 .

50 Even al-Hajiāj is said to have found the example of Muscab's noble death compelling: facing the difficulty of fighting the threatening khäriji leader Shabīb, his supporters tried to convince him to turn back. Al-Hajjāj, as reported in al-Aghānī, asked rhetorically, "Hal taraka Muṣ'ab" li-karīm ${ }^{\text {in }}$ mafarr ${ }^{a n}$ ?" (Has Muṣ'ab left the noble man the possibility of fleeing?) Al-IȘFAHĀNī, Aghānī, xix: 89 (“maqtal Muș'ab b. al-Zubayr"). 
Sunni historiographic tradition, the point was likely not to establish with certainty that the deaths portrayed were indeed the deaths of martyrs but rather to suggest it. Only God could know for certain.

Needless to say, the historical information conveyed in these texts is useful for understanding the values, the concerns, and the ideals of later Muslims. Like other rhetorical arenas in Islamic historiography, however, they cannot be considered straightforward reports of what men actually said or did upon or before dying in battle. They were probably never understood to be exactly that by early Muslim scholars: as GOLDZIHER argued was the case for moral or ethical hadiths, I believe that one should assume that Muslim historians transmitted maqaitil accounts with the understanding that some fabrication, some degree of creative transmission, was tolerable if it enhanced their edifying value, their redemptive function, and their dramatic appeal. ${ }^{51}$ Elaboration rendered accounts more distinctly edifying, and helped the audience to understand the meaning of the past.

This does not mean that the basic facts of the events are untrue. We can assume that Mușab b. al-Zubayr was killed near Maskin, in a battle with 'Abd al-Malik's forces, and that his son 'Īsā was killed there as well. ${ }^{52}$ But did Muș ab call someone to describe the forbearance of al-Husayn and his supporters before going out to battle? Did he recite poetry? Perhaps: it is not entirely unreasonable, as modern studies of poetry in Arab societies remind us - poetry was an important element in Arab life then, as it still is in many parts of the Arab world, known to many who might recite apposite lines in a time of crisis. ${ }^{53}$ But if he did not, perhaps historians and transmitters understood that he should be remembered as having done so, since to portray Mușab in his last moments invoking the memory of alHusayn's last moments through poetry renders the story of Mus ab's death more evocative and suggests a direct parallel between him and the Shīi figure of al-Husayn.

The same is of course true of the death of 'Abd Allāh b. al-Zubayr: we can trust that he and his forces survived the first siege of Mecca, and fell in the second siege and campaign against him. But did he consult his mother, and explain to her his comportment and motivation? This seems highly doubtful. She had not been previously cut off from contact with him; could it be that it was only just before his death that he found time to explain himself to her? The entire reported conversation between 'Abd Allāh and his mother in these texts functions as a vehicle for presenting a distillation of his character and cause, for answering the questions later Muslims would have wanted answered.

Maqātil summed up individuals' lives, causes and ultimate values by portraying their last words and final acts. They indirectly answered the question of how pious Muslim forebears could have fought other Muslims unto death (by fighting for righteousness). They gave clues about whether or not they might be considered martyrs. They thus functioned as an arena of redemptive memory, redeeming an otherwise troubled past, in which men famed for their piety were slain as if God had abandoned them, and esteemed forebears fought unto death. They were also inspirational texts, as has been shown. And in the late antique world in which these accounts were transmitted, narratives about martyrs

51 GOLDZIHER 1967: 145-153, et passim.

52 These are the kinds of "facts" that remain undisputed within the tradition, and seem to be resistant to modification. See CRONE 1980.

53 The classic works on this include: ABU LUGHOD 1986, BAILEY 1991, and CATON 1990. 
commonly served to emotionally bind people to perceived forebears in communities of suffering and courageous righteousness. ${ }^{54}$ Maqätil appear to have fulfilled some of this role, binding later Muslims to pious Sunni forebears. Moreover, combining elements of tragedy, religious commitment, and heroic sacrifice, they were compelling to recount and to read.

Maqātil thus served both religious and literary functions in this historical tradition They evocatively illustrated for posterity historical characters' most deeply-held values, suggested possibilities about their ultimate fates, and helped to explain, in the case of Companions and Successors, how it could have come to pass that these esteemed forebears of the community had fought each other unto death. In the cases of Muș ab and 'Abd Allāh, accounts of how these men had nobly faced death for the sake of a primordial "purity of faith" supplied certain later Sunnis, when they felt communally threatened, with narratives that could engender a sense of belonging to a stable group with ancient, legitimate roots in the lives of the Companions and Successors. ${ }^{55}$ The maqātil of the two sons of al-Zubayr explored here reflect the literary, interpretive and inspirational functions of Islamic historical narratives, as well as some of the concerns that shaped how the early history of the Islamic community was remembered and retold.

\section{Bibliography}

\section{Primary Sources}

ABŪ 'L-'ARAB, Muhammad b. Aḥmad al-TAMīMĪ. Kitāb al-miḥan. Ed. Yahyā Wahīb al-JUBŪRī. Beirut: Dār al-gharb al-islāmī, 1983.

al-BAGHDĀDĪ, al-Khațīb. Ta'rīkh Baghdād, xiii. Beirut: Dār al-kutub al-'ilmiyya, 1349/1931.

al-BALĀDHURĪ, Ahmad. Ansāb al-ashrāf. Ed. S. D. F. GoITEIN. Jerusalem: Hebrew University School of Oriental Studies, 1936.

_ـ Ansāb al-ashrāf. Ed. Iḥsān `ABBĀs. Beirut: Franz Steiner, 1996.

al-DīnAwarī, Abū Ḥan̄ifa Aḥmad b. Dāwūd. al-Akhbār al-Tịwāl. Ed. 'Abd al-Mun ìm 'ĀMir. Cairo: Wizārat al-thaqāfa wa-'l-irshād al-qawmī, 1960.

IBN AL-ATHīr, 'Izz al-Dīn 'Alī. al-Kāmil fì 'l-Ta'rīkh. Beirut: Dār Șādir, 1966.

IBN AL-ḤAJJĀJ, Muslim. Șaḥịh Muslim bi-sharh al-Nawawī. Cairo: Dār al-ḥadīth, 1994.

IBN KATHĪr, Abū al-Fidā'. al-Bidāya wa'l-nihāya. Ed. Aḥmad 'Abd al-Wahhāb FuTAYYıḤ. 16 vols. Cairo: Dār al-ḥadìth, 1998.

IBN KHAYYĀṬ, Khalīfa. Ta'rīkh. Beirut: Dār al-fikr, 1993.

IBN MANZūR, Jamāl al-Dīn Muhammad. Lisān al-'Arab. Beirut: Dār Șādir, 1990.

IBN SA 'D. al-Ṭabaqāt al-kubrāa. Ed. Muhammad 'Abd al-Qādir 'AṬ̂̄'. 8 vols. Beirut: Dār al-kutub al'ilmiyya, 1990.

al-IȘFAHĀNī, Abū al-Faraj. Kitāb al-Aghānī. Beirut: Dār iḥyā’ al-turāth al-'arabī , 1994.

al-KūFī, Abū Muḥammad Aḥmad b. A'tham. Kitāo al-Futūḥ. Ed. Muhammad 'ABD AL-Mu'īD KHĀN. Beirut: Dār al-nadwa al-jadīda, n.d.

al-MAS' ŪDĪ, 'Alī b. al-Ḥusayn. Murūj al-dhahab wa-ma'ādin al-jawhar. Ed. Muḥammad Muhȳī al-

54 On the function of "the shared remembrance" of martyrs "inscribed in literary texts" as a means of uniting members of religious or political communities into "communities of suffering," see PANNEWICK 2004a: 9-12 and PANNEWICK 2004b, 48-57.

55 On those rituals, see CAMPBELL 2003, as noted above. 
Dīn 'ABD AL-ḤAmīD. Beirut: Dār al-fikr, n.d.

al-ṬABAR̄̄, Abū Ja far Muhammad b. Jarīr. Annales quos scripsit Abu Djafar Mohammed Ibn Djarir At-Tabari. Ed. M. J. De GoEJE. series 2. Leiden: E. J. Brill, 1964.

_ . Ta'rīkh al-rusul wa'l-mulūk. Ed. Muhammad Abū al-Faḍl IBRĀHĪM. Cairo: Dār al-Ma'ārif, 1964.

. History of al-Tabarī: the Victory of the Marwānids, trans. Michael FisHBEIN. Albany: SUNY Press, 1990.

al-TANŪKHĪ, Abū 'Alī al-Muhsin b. 'Alī. al-Faraj ba'd al-shidda. Ed. 'Abbūd al-ThĀLIJ̄̄. Beirut: Dār Șādir, 1978.

al-YA 'QŪBĪ, Aḥmad. Ta'rīkh. Beirut: Dār Șādir, n.d.

\section{Secondary Studies}

'AbD Dixon, 'Abd al-Ameer. 1971. The Umayyad Caliphate. Luzac and Co., London.

ABOU EL-FADL, Khalid. 2001. Rebellion and Violence in Islamic Law. Cambridge University Press, Cambridge.

Abu Lughod, Lila. 1986. Veiled Sentiments: Honor and Poetry in a Bedouin Society. University of California Press, Berkeley \& Los Angeles.

AghaIE, Kamran Scot. 2004. The Martyrs of Karbala: Shi i Symbols and Rituals in Modern Iran. University of Washington Press, Seattle.

Ayoub, Mahmoud. 1978. Redemptive Suffering in Islam: a Study of the Devotional Aspects of 'Āshūrä' in Twelver Shi ism. Mouton, The Hague.

BAIley, Clinton. 1991. Bedouin Poetry from Sinai and the Negev: Mirror of a Culture. Oxford University Press, Oxford.

Beaumont, Daniel. 1996. "Hard-Boiled: Narrative Discourse in Early Muslim Traditions". Studia Islamica 83,1: 5-31.

Brock, Sebastian, and Susan Harvey. 1987. Holy Women of the Syrian Orient. University of California Press, Berkeley.

CAmpBell, Sandra. 2003. Telling Memories: the Zubayrids in Historical Memory. Ph.D. Dissertation, UCLA.

CAton, Steven. 1990. Peaks of Yemen I Summon: Poetry as Cultural Practice in a North Yemeni Tribe. University of California Press, Berkeley \& Los Angeles.

Cooperson, Michael. 2000. Classical Arabic Biography: the Heirs of the Prophet in the Age of alMa'mūn. Cambridge University Press, Cambridge.

Crone, Patricia. 1980. Slaves on Horses: the Evolution of the Islamic Polity. Cambridge University Press, Cambridge.

EL-HiBRI, Tayeb. 1999. Re-interpreting Islamic Historiography: Hārūn al-Rashīd and the Narrative of the 'Abbāsid Caliphate. Cambridge University Press, Cambridge.

GoldziHer, Ignaz. 1967. Muslim Studies. Trans. C. R. Barber and S. M. Stern. George Allen \& Unwin Ltd., London.

GÜNTHER, Sebastian. 1994. "Maqātil Literature in Medieval Islam”. Journal of Arabic Literature 25,3: 192-212.

_. 1991. Quellenuntersuchungen zu den "Maqātil at-Tālibiyyīn" des Abū 'l-Farağ al-Isfahānī. Georg Olms Verlag, Hildesheim.

KHALIDI, Tarif. 1975. Islamic Historiography: the Histories of al-Mas'ūdī. SUNY Press, Albany.

KINBERG, Leah. 1993. "Literal Dreams and Prophetic Hadiths in Classical Islam: a Comparison of Two Ways of Legitimation," Der Islam: Zeitschrift für Geschichte und Kultur des islamischen Orients 70,2: 279-300.

_ 1986. "Interaction between this World and the Afterworld in Early Islamic Tradition". Oriens 29/30: 285-308. 
Kohlberg, Etan. 1997. Medieval Muslim Views on Martyrdom. Koninklije Nederlandse Akademie van Wetenschappen, Amsterdam. (New Series; vol. 60,1).

. 1997a. "Shahīd". Encyclopaedia of Islam, New Edition. Ed. C. E. Bosworth et al. Volume IX: 203-206.

LANE, Edward W. 1863. An Arabic-English Lexicon. Ed. Stanley Lane Poole. Islamic Texts Society, Cambridge.

MeISAMI, Julie Scott. 1995. "Exemplary Lives, Exemplary Deaths: the Execution of Hasanak". Papers presented at the XVI Congreso Union Européene d'Arabisants et d'Islamisants. N.p., Salamanca, Spain.

Morony, Michael. 1984. Iraq After the Muslim Conquest. Princeton University Press, Princeton.

NeuwirTh, Angelika. 2004. "From Sacrilege to Sacrifice: Observation on Violent Death in Classical and Modern Arabic Poetry”. In: PANNEWICK (ed.) 2004: 259-282

Noth, Albrecht / CONRAD, Lawrence. 1994. The Early Arabic Historical Tradition: A Source Critical Study. Trans. by Michael Bonner. $2^{\text {nd }}$ ed. Darwin Press, Princeton.

PanNewick, Friederike (ed.). 2004. Martyrdom in Literature: Visions of Death and Meaningful Suffering in Europe and the Middle East from Antiquity to Modernity. Reichert Verlag, Wiesbaden. - . 2004a. "Introduction." In: PANNEWICK (ed.) 2004: 1-28.

. 2004b. "Passion and Rebellion: Shīîte Visions of Redemptive Martyrdom." In: PANNEwick (ed.) 2004: 47-62

PinAult, David. 2001. Horse of Karbala: Muslim Devotional Life in India. Palgrave Macmillan.

Rosenthal, Franz. 1968. A History of Muslim Historiography.Brill, Leiden.

SizGORICH, Thomas. 2009. Violence and Belief in Late Antiquity. University of Pennsylvania Press, Philadelphia.

SZYSKA, Christian. 2004. "Martyrdom: a Drama of Foundation and Transition." In: PANNEWICK (ed.) 2004: 29-45.

SANDRA CAMPBEll, Department of History, San Diego State University, San Diego CA, USA

\campbel14425@gmail.com, sandscamp@gmail.com 